\section{School science faces reform}

\section{Washington}

THIRTY years after Sputnik launched the space age and the short-lived renaissance of US science education, government officials are hoping to regain those glory days with a radical rethinking of education. In the first set of major reforms since the 1950 s, federal policy-makers are preparing to set a national agenda for science instruction in the pre-college years, led by a new presidential education initiative to be announced early next year.

Joining the government in the battle to save US science education, two national organizations are preparing programmes that would have the effect of totally restructuring science teaching on a national scale - a substantial change from the regional approach that now dictates how most US students learn science.

Since the mid-1950s, US science and mathematics education has declined in virtually every category. Searching for an explanation, policy-makers have pointed to teachers who have lost touch with the research world, teaching methods that date back decades and a general resistance to new educational materials. A series of international comparisons each more devastating than the last, has fuelled the debate for educational reform.

Thomas Ratchford, associate director for policy and international affairs in the White House Office of Science and Technology Policy acknowledges that "at the $\mathrm{K}-12$ [between the ages 5 to 17 or 18] level, we are in deep trouble", and says that reform is a top priority for this administration. In a speech raising the issue last year, President Bush pledged that, "by the year 2000 , US students will be the first in the world in science and mathematics achievement".

One of the major obstacles to reform is the sheer size of the US education system, which serves 46 million children in 80,000 schools within 16,000 school districts. The decentralization of authority and allocation of resources make the capacity for rapid change impossible. The responsibility for education rests primarily with the state legislators and the local school boards, and there is no intention on the part of the administration to change that situation, says Ratchford.

Although the federal role in education is relatively small - less than 6 per cent of the $\$ 200$ thousand million that is spent annually on education - Ratchford believes that injecting more money into science education is not the answer. Investment in pre-college education has increased in real terms over the past ten years and "we have very little, if anything, to show for it in terms of test scores".

In order to achieve maximum leverage in science education with limited resour- ces, the administration has set up an Education and Human Resources Committee within the Federal Coordinating Council on Science, Education and Technology (FCCSET), a body led by the president's science adviser and made up of top officials from 11 science-related agencies (see Nature 348, 97; 8 November 1990). The committee will address policy issues that cross agency lines, identifying gaps, promoting increased agency cooperation and eliminating unnecessary duplication. The primary focus of the interagency effort will be pre-college education, which is a priority in the president's national goals for education. Specific targets of the science-education initiative will be announced in the president's January budget request for 1992 .

The United States has no nationally mandated curriculum for science, although most states require students to study science of some sort for a minimum of two years in order to graduate from high school. In general, the United States adopts the 'layer-cake' approach to science teaching, where each subject is taught as a condensed year-long course with no attempt being made to integrate the disciplines. Students take biology one year, chemistry the next, physics the year after. More than 50 per cent of students opt out of science at the first opportunity, and only 19 per cent of high-school graduates have studied physics as a single subject; 40 per cent take chemistry.

NSTA's Scope, Sequence and Coordination (SS\&C) Project and Project 2061, run by the American Association for the Advancement of Science (AAAS), offer

\section{Washington}

SIX months after he was fired from the top National Science Foundation (NSF) education post for his outspoken criticism of the US educational efforts, Bassam Shakhashiri is back in the classroom. Now a chemistry professor at the University of Wisconsin, Shakhashiri argues that simply restructuring federal support of US science education will not be enough to halt the country's precipitous educational decline.

Six years ago, when Shakhashiri joined NSF during the Reagan administration, educational activities at the agency had been all but shut down. But during the next half-decade, Shakhashiri's singleminded effort to raise the profile of NSF in science and mathematics education helped to boost the annual budget from $\$ 50$ million to more than $\$ 300$ million.

Yet even that is not enough, says

two different approaches to a parallel problem - the total restructuring of science teaching on a national scale. The SS\&C initiative, which is funded by the National Science Foundation (NSF) and the Department of Education (DoEd), calls for a scrapping of the layer-cake approach and recommends that all students learn biology, chemistry, physics and Earth/space science each year for six years in grades 7-12. Experimental trials with SS\&C began in September in selected schools at five sites, including the state of California and the Houston Independent School District.

By contrast, Project 2061 is a threephase 25-year effort designed to raise the scientific literacy of all Americans, with the expectation that this would provide "a greater pool from which to entice future scientists", says Jo Ellen Roseman, curriculum director of Project 2061. Science for All Americans, the product of phase I, re-examines the education process from kindergarten right through to high school and establishes learning goals in science, mathematics and technology. A variety of curriculum models should be available by spring 1993 .

The United States may be in a new era of educational reform, but being able to turn the situation around is far beyond the ability of any one single sector to influence. Nationwide reform will need to encompass all aspects of the education system. If the focus is only on teachers and a school's organization or its curriculum do not change, those teachers will "have brilliant ideas and no place to take them", says David Florio, director of policy studies in DoEd's Office of Evaluation and Research.

Diane Gershon

\title{
Massive change needed to halt decline
}

Shakhashiri, who feels that "what is needed is $\$ 600$ million, so that NSF can exert its leadership role among the scientific, educational and business communities ... to bring about statewide systemic change".

Shakhashiri makes it clear that he is not interested in incremental change. The situation that the United States now faces "is, by far, more serious and more consequential than that faced in the immediate post-Sputnik era", he says.

Then, reform efforts in the United States concentrated on regaining preeminence in the fields of science, mathematics and engineering. In what Shakhashiri describes as a twin mission, he acknowledges the need for continued support of the best and the brightest students, but is emphatic about the need to communicate science to the non-scientists. Diane Gershon 